\title{
Biosorption of Lead and Nickel by Biomass of Marine Algae
}

\author{
Z. R. Holan and B. Volesky* \\ Department of Chemical Engineering, McGill University, Montreal, Canada \\ H3A $2 A 7$
}

Received July 14, 1993/Accepted November 22, 1993

Screening tests of different marine algae biomass types revealed a high passive biosorptive uptake of lead up to $270 \mathrm{mg} \mathrm{Pb} / \mathrm{g}$ of biomass in some brown marine algae. Members of the order Fucales performed particularly well in this descending sequence: Fucus $>$ Ascophyllum > Sargassum. Although decreasing the swelling of wetted biomass particles, their reinforcement by crosslinking may significantly affect the biosorption performance. Lead uptakes up to $370 \mathrm{mg} \mathrm{Pb} / \mathrm{g}$ were observed in crosslinked Fucus vesiculosus and Ascophyllum nodosum. At low equilibrium residual concentrations of lead in solution, however, ion exchange resin Amberlite IR-120 had a higher lead uptake than the biosorbent materials. An order-of-magnitude lower uptake of nickel was observed in all of the sorbent materials examined. (C) 1994 John Wiley \& Sons, Inc.

Key words: lead biosorption - nickel biosorption - brown algae - seaweeds - biosorption screening - biosorption of heavy metals - metal uptake

\section{INTRODUCTION}

There has been ample evidence of passive metal uptake observed with certain types of microbial biomass. Although scattered in a variety of research contributions, it has been summarized in a recently published book ${ }^{26}$ which also outlines the potential of this phenomenon termed biosorption. Interest has primarily focused on heavy metals due to their known toxicity as they are discharged in small quantities by numerous industrial activities into the environment, where they tend to accumulate, being concentrated throughout the food chain. This aspect coupled with their persistence results in a serious health hazard threatening water supplies and populations depending on them.

Lead has been known for its toxicity for a long time, and increasing uses of nickel, particularly in metal plating, lead to rising concerns. These and other metals have been detected in some algal populations in different parts of the world. ${ }^{1,8,24}$ Studies focusing specifically on nickel are rare. ${ }^{23,30}$ Previous work mostly covered the sorption of nickel in a range of other heavy metals., ${ }^{2,9,13}$ The information is mostly relevant to the description of metal accumulation by living plants or to the toxic effects of metals on their metabolism. Sometimes the levels of metals found in algal biomass served to detect the water contamination by metallic species. These studies are predominantly of an ecological orientation. ${ }^{28-30}$

\footnotetext{
* To whom all correspondence should be addressed.
}

The potential of some freshwater algae biomass for metal binding has been recognized earlier, ${ }^{11}$ leading to the focus on technological aspects of removal and recovery of heavy metals. ${ }^{716}$ While toxicological studies with heavy metals in marine algae prevail, passive biosorption of heavy metals by seaweed materials has been studied only recently, ${ }^{14,17}$ revealing the interesting potential of these abundant natural materials. $^{26,27}$

This work, continuing the exploratory line of studies, compares the sorption of lead and nickel by selected marine algal biomass types abundantly available in the oceans.

\section{MATERIALS AND METHODS}

\section{Biomass}

The origin and treatment of brown algae (Phaeophyta) Ascophyllum nodosum, Fucus vesiculosus, and Sargassum natans were described earlier. ${ }^{14}$ Sargassum fluitans came from the Caribbean (courtesy of L. Almodovar, University of Puerto Rico); Sargassum vulgare and Padina gymnospora were collected in Rio de Janeiro (courtesy of A. B. Pacheco, Jardino Botanico). Green alga (Chlorophyta) Codium taylori came from Australia (courtesy of H. Mann, on leave from the University of Western Ontario, London, Ontario). Red algae (Rhodophyta) Chondrus crispus, Galaxaura marginata, and Palmaria palmata came respectively from the Caribbean, Rio de Janeiro, and Atlantic Mariculture, Gand Maman, New Brunswick, Canada.

\section{Chemicals}

The origin of the chemicals used was mentioned previously. ${ }^{14}$ Analytical grades of $\mathrm{Pb}\left(\mathrm{NO}_{3}\right)_{2}, \mathrm{NiCl}_{2}$. $6 \mathrm{H}_{2} \mathrm{O}$, and $\mathrm{HNO}_{3}(70 \%)$ were purchased from $\mathrm{BDH}$ (Toronto, ON), and Fischer Scientific (Fair Lawn, NJ), respectively. Lead $(1000 \mathrm{mg} / \mathrm{L}$ and nickel $1005 \mathrm{mg} / \mathrm{L})$ atomic absorption standard solutions were obtained respectively from Fischer Scientific (Fair Lawn, NJ) and Aldrich Chemical Company (Milwaukee, WI).

\section{Methods}

The metal uptake $(q)$ was calculated from the initial concentration $\left(C_{2}\right)$ and the analyzed final concentration $\left(C_{f}\right)$ of 
the metal in solution according to the following formula:

$$
q=V\left(C_{i}-C_{f}\right) / M
$$

where $V$ is the liquid sample volume and $M$ the starting sorbent weight. Sorption isotherms were constructed from the experimental points by the spline method. The Langmuir sorption model,

$$
q=b C_{f} q_{\max } /\left(1+b C_{f}\right)
$$

was also computer-fitted to the experimental points for comparison, summarized in the tables. ${ }^{14}$ Langmuir parameters $q_{\max }$ (the maximum uptake) and $b$ (a constant related to energy of adsorption) are useful in quantitatively comparing the sorption performance.

A constant $\mathrm{pH}$ for the batch equilibrium sorption experiments was maintained at $\mathrm{pH} 3.5,4.5$, and 6.0, respectively, by periodically adjusting it with $0.1 M \mathrm{NH}_{4} \mathrm{OH}$ or 0.1 to $0.5 \mathrm{M} \mathrm{HNO}_{3}$ in the case of lead sorption. Constant $\mathrm{pH}$ levels of nickel solutions were maintained by adjustments with the same concentration of either $\mathrm{NaOH}$ or 0.1 to $0.5 \mathrm{M} \mathrm{HCl}$. The content of $\mathrm{CaCO}_{3}$ in calcareous algae ( $25 \mathrm{~g}$ biomass per $750 \mathrm{~mL}$ distilled water) was destroyed and estimated titrimetrically with $0.5 \mathrm{M} \mathrm{HCl}$ until constant $\mathrm{pH}$ 5. The sorption temperature was kept at approximately $25^{\circ} \mathrm{C}$ due to the fact that sorption of lead by algae tends to slightly increase in the range 4 to $55^{\circ} \mathrm{C}$. The sorption of nickel was temperature independent. ${ }^{11}$

The final equilibrium concentrations of lead and nickel in aqueous samples were determined by a Perkin-Elmer atomic absorption spectrometer (model 3100) at 261.5 and $341.5 \mathrm{~nm}$, respectively. Other methods, including the determination of particle ( size $>1.0 ;<1.4 \mathrm{~nm}$ ) swelling characteristics and methods of crosslinking, have been described earlier. ${ }^{14}$

\section{RESULTS}

\section{Lead}

Equilibrium batch sorption experiments resulted in points of the "biosorption isotherm" which was approximated by the Langmuir model. It is essential to compare the performance of the tested materials at the same equilibrium concentration of the metal in the residual solution. This can be conveniently done from their respective sorption isotherm plots. However, since the biosorption performance may not necessarily follow that predicted by the Langmuir sorption model, the deviation is of interest, as is the maximum metal uptake for each material examined. Both experimental and calculated results of equilibrium sorption experiments are summarized in Tables I and II. The experimental curves represent the best empirical fit through the given experimental points. Metal uptakes at equilibrium residual concentrations $\left(C_{f}\right)$ of 10 and $200 \mathrm{mg}$ metal/L were selected for comparison purposes, representing arbitrarily chosen "low" and "high" metal residual concentrations. The Langmuir parameter $b$ reflects quanti- tatively the "affinity" between the sorbent and the sorbate. Its informative values are also included in Tables I and II.

Rough screening for metal sorption was performed with 45 algal biomass samples (native and crosslinked) using solutions with the initial $\left(C_{f}\right)$ concentration of lead at $250 \mathrm{mg} \mathrm{Pb} / \mathrm{L}$. The best performing biomass types were examined in more detail. The comparison of lead sorption by different types of algal biomass (native as well as crosslinked) is summarized in Table I, grouping the biomass types according to their taxonomy. The results show that biosorption of lead by the selected marine algal biomass is considerable, particularly considering that there was no pretreatment of the biomass. In general, the lead biosorbent uptake decreased in the following sequence: Phaeophyta $>$ Chlorophyta $>$ Rhodophyta. Among the Phaeophyta the lead biosorption decreased as follows: Fucus $>$ Ascophyllum $>$ Sargassum $>$ Padina. Among the Rhodophyta the decreasing order of lead biosorption was Galaxaura $>$ Chondrus $>$ Palmaria.

There were two calcareous algae examined: Padina gymnospora (Phaeophyta) with $4.4 \%$ structural limestone and Galaxaura marginata (Rhodophyta) with $28.6 \%$ aragonite in intracellular spaces. The removal of $\mathrm{CaCO}_{3}$ resulted in the $50 \%$ drop of lead $q_{\max }$ in $P$. gymnospora, whereas the same pretreatment resulted in $1277 \%$ increase of the lead $q_{\max }$ in $G$. marginata. The interspecies diversity of biosorption was demonstrated in the genus Sargassum, where the lead $q_{\max }$ decreased as $S$. fluitans $>S$. natans $>$ $S$. vulgare, with only the latter having a significantly lower (by approximately 15\%) lead uptake.

The increasing uptake of lead by $F$. vesiculosus and $A$. nodosum with increasing $\mathrm{pH}$ is demonstrated in Figures 1 and 2 , respectively. The figures also show the $\mathrm{pH}$ values established in the sorption systems where $\mathrm{pH}$ was not controlled. Obviously, the $\mathrm{pH}$ data points in the Figures represent the equilibrium values corresponding to different final concentrations reached in the sorption system, not the time course of the sorption. Individual metal uptake $(q)$ data points from these control experiments are not connected because they do not represent the same sorption isotherm since each point was characterized by a different $\mathrm{pH}$ value.

Particularly the ends of sorption isotherms for $F$. vesiculosus (Fig. 1) at very high residual metal concentrations are distorted by metal complexes formed as colloids occurring in the solution due to the leaching of water-soluble biopolymers (probably alginates) from the biomass (R. P. de Carvalho, personal communication). The last points of these isotherms were not considered in the calculation of theoretical maximum metal uptakes (Langmuir $q_{\max }$ ) and coefficient $b$ because they do not represent the metal removal by sorption but rather due to filtration at the end of the experiment. Consequently, the values of $q_{\max }$ for those unconventional S-shaped sorption isotherms (Fig. 1 to 3) quoted in Table II ought to be considered only as approximative values. Dry weights of supernatants from control experiments containing only water showed that $F$. vesiculosus biomass gradually released water-soluble 
Table I. Experimental and calculated lead uptake by different types of sorbent materials at pH 3.5.

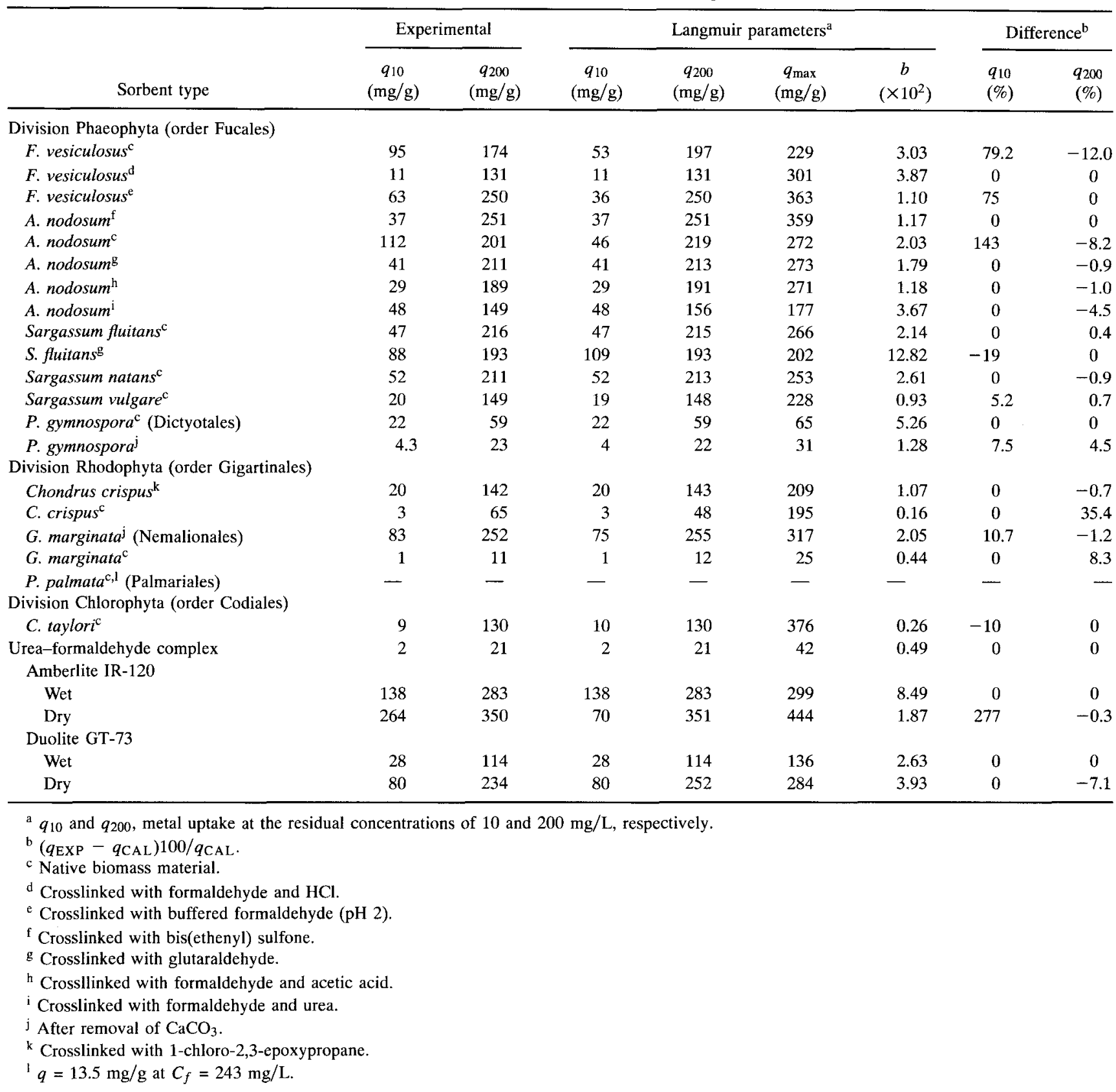

material up to $37 \%$ of native biomass (not crosslinked) dry weight after $24 \mathrm{~h}$ of shaking. This value remained the same for both $\mathrm{pH}$ nonadjusted systems and for the controlled $\mathrm{pH}$ range 3.5-6.0 (no-metal blanks). The sorption uptake values, however, were always calculated based on the initial mass of the biosorbent. The two equilibrium $\mathrm{pH}$ curves for sorption systems without $\mathrm{pH}$ control in Figure 1 show slightly lower $\mathrm{pH}$ values resulting after $12 \mathrm{~h}$ of contact as opposed to $1 \mathrm{~h}$ of contact. The bulk of the sorbed metal is sorbed much faster than that as indicated by the preliminary sorption kinetic experiments (not reported here). However, although the sorption equilibrium exists for all practical purposes, leaching of the (polysaccharide) biomass material is slower, and it seems to interact with the residual metal in the solution, thus disturbing the true sorption equilibrium in the system to a small degree.

Visible precipitate in the sorption suspension was formed above $C_{i}=250 \mathrm{mg} \mathrm{Pb} / \mathrm{L}$ in all four series of experiments with $F$. vesiculosus. The formation of precipitate was not entirely due to the formation of lead hydroxides. No formation of precipitate was observed in the range of $C_{i}$ up to $250 \mathrm{mg} \mathrm{Pb} / \mathrm{L}$ where the metal was sorbed by solid biomass preferentially to the soluble biopolymers. Only very light "haze" was observed in the solutions of contact systems with $C_{i}$ above $500 \mathrm{mg} \mathrm{Pb} / \mathrm{L}$. Increasing values of $\mathrm{pH}$ in the contact systems resulted in irregular S-shaped isotherm curves reflecting the sorption "enhancement" by formation of insoluble lead hydroxides. A good comparison 
Table II. Experimental and calculated lead uptake by different types of native materials at different pH.

\begin{tabular}{|c|c|c|c|c|c|c|c|c|}
\hline \multirow[b]{2}{*}{ Sorbent type } & \multicolumn{2}{|c|}{ Experimental } & \multicolumn{4}{|c|}{ Langmuir parameters $^{\mathrm{a}}$} & \multicolumn{2}{|c|}{ Difference $^{b}$} \\
\hline & $\begin{array}{c}q_{10} \\
(\mathrm{mg} / \mathrm{g})\end{array}$ & $\begin{array}{c}q_{200} \\
(\mathrm{mg} / \mathrm{g})\end{array}$ & $\begin{array}{c}q_{10} \\
(\mathrm{mg} / \mathrm{g})\end{array}$ & $\begin{array}{c}q_{200} \\
(\mathrm{mg} / \mathrm{g})\end{array}$ & $\begin{array}{c}q_{\max } \\
(\mathrm{mg} / \mathrm{g})\end{array}$ & $\begin{array}{c}b \\
\left(\times 10^{2}\right)\end{array}$ & $\begin{array}{l}q_{10} \\
(\%)\end{array}$ & $\begin{array}{l}q 200 \\
(\%)\end{array}$ \\
\hline \multicolumn{9}{|c|}{ Division Phaeophyta (order Fucales) } \\
\hline \multicolumn{9}{|c|}{$F$. vesiculosus } \\
\hline Nonadjusted $\mathrm{pH}$ & $103(\mathrm{pH} \mathrm{3.7)}$ & $216(\mathrm{pH} \mathrm{3.5)}$ & - & - & - & - & - & - \\
\hline $\mathrm{pH} 3.5$ & 95 & 174 & 53 & 197 & 229 & 3.03 & 79 & -12.0 \\
\hline $\mathrm{pH} 4.5$ & 101 & 316 & 70 & 376 & 489 & 1.67 & 44 & -16.1 \\
\hline pH 6.0 & 114 & 336 & 80 & 453 & 600 & 1.55 & 43 & -26.0 \\
\hline \multicolumn{9}{|l|}{ A. nodosum } \\
\hline Nonadjusted pH & $115(\mathrm{pH} \mathrm{4.6)}$ & $211(\mathrm{pH} \mathrm{4})$ & - & - & - & - & - & - \\
\hline $\mathrm{pH} 3.5$ & 112 & 201 & 46 & 218 & 272 & 2.03 & 143 & -7.8 \\
\hline $\mathrm{pH} 4.5$ & 115 & 219 & 34 & 240 & 354 & 1.05 & 238 & -8.8 \\
\hline $\mathrm{pH} 6.0$ & 130 & 280 & 77 & 379 & 478 & 1.90 & 69 & -26.1 \\
\hline \multicolumn{9}{|l|}{ Amberlite IR-120 (dry) } \\
\hline Nonadjusted $\mathrm{pH}$ & $290(\mathrm{pH} \mathrm{4.4)}$ & $393(\mathrm{pH} 4)$ & - & - & - & 一 & - & - \\
\hline $\mathrm{pH} 3.5$ & 264 & 350 & 70 & 351 & 444 & 1.87 & 277 & -0.3 \\
\hline $\mathrm{pH} 4.5$ & 333 & 453 & 106 & 487 & 602 & 2.13 & 214 & -7.0 \\
\hline $\mathrm{pH} 6.0$ & 408 & 855 & 246 & 895 & 1039 & 3.11 & 66 & -4.5 \\
\hline
\end{tabular}

a $q_{10}$ and $q_{200}$ metal uptake at the residual concentrations of 10 and $200 \mathrm{mg} / \mathrm{L}$, respectively.

${ }^{\mathrm{b}}\left(q_{\mathrm{EXP}}-q_{\mathrm{CAL}}\right) 100 / q_{\mathrm{CAL}}$

of sorption performance at $q_{\max }$ cannot be made due to the isotherm anomalies showing at high $\mathrm{Pb}$ residual concentrations. More meaningful comparison can be made for values of $q_{200}$.

If experimental lead uptake $q_{200}$ by native biomass of $F$. vesiculosus at $\mathrm{pH} 6$ is considered $100 \%(336 \mathrm{mg} / \mathrm{g})$, lead $q_{200}$ values would be $94 \%$ and $52 \%$ for $\mathrm{pH} 4.5$ and 3.5 , respectively. A corresponding comparison for A. nodosum would be $78 \%$ and $72 \%$. Even though the final difference in $\mathrm{pH}$ values between the $\mathrm{pH}$ nonadjusted system (final $\mathrm{pH} 3.8$ ) and that with constant $\mathrm{pH} 3.5$ was only $0.3 \mathrm{pH}$ units, this small difference resulted in $24 \%$ higher $q_{200}$ in the $F$. vesiculosus sorption system with variable $\mathrm{pH}$. There was no such difference for the $A$. nodosum sorption systems. The values of $q_{10}, q_{200}, q_{\max }$, and $b$ at different $\mathrm{pH}$ values

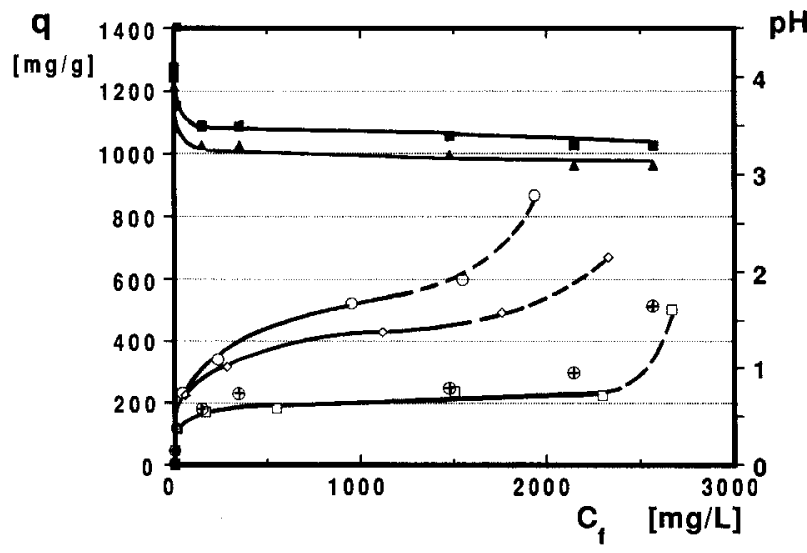

Figure 1. Experimental lead sorption isotherms for dead native biomass of $F$. vesiculosus at different $\mathrm{pH}:(\square) \mathrm{pH} 3.5 ;(\diamond) \mathrm{pH} 4.5 ;(\bigcirc) \mathrm{pH} 6.0$. $(---)$ Combined biosorption and precipitation metal removal. $(\oplus)$ Nonadjusted pH metal uptake values after $(\square) \mathbf{~ h}$ and $(\boldsymbol{\Delta}) 12 \mathrm{~h}$ of contact (starting $\mathrm{pH} 4.6$ ). for native biomass sorption systems are summarized in Table II. Generally, the differences between experimental and calculated values are small for values of $q_{200}$ but relatively larger for $q_{10}$. Experimental values for $q_{10}$ are usually 2 to 3 times higher in comparison with the ones predicted by the Langmuir model, which obviously was not well followed at low concentrations. The differences between experimental and model-predicted values showed a decreasing tendency with increasing values of metal uptake and $\mathrm{pH}$.

Figure 2 shows the sorption performance of $A$. nodosum native biomass at different constant $\mathrm{pH}$ values. The figure also shows the $\mathrm{pH}$ decrease in the controls with no $\mathrm{pH}$ adjustment. Although the metal solution starting $\mathrm{pH}$ was 4.6, it increased immediately as biomass was added to $\mathrm{pH}$ 5.7. Further $\mathrm{pH}$ decrease in the $A$. nodosum sorption

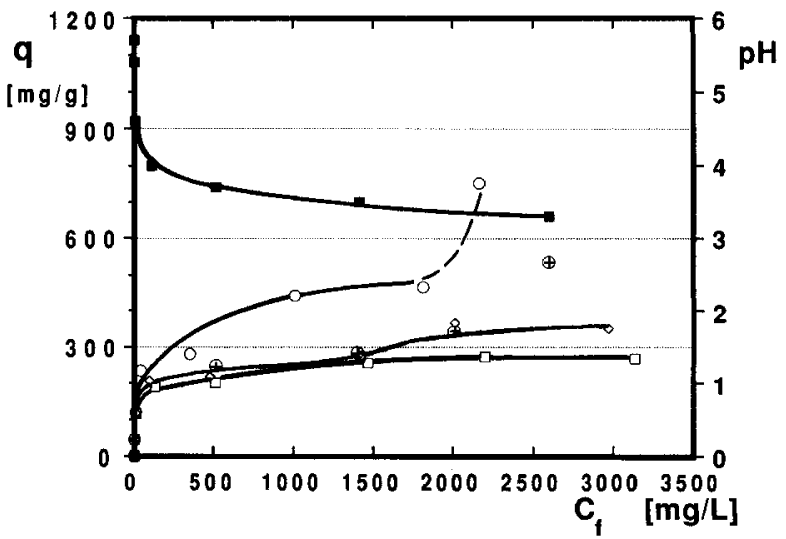

Figure 2. Experimental sorption isotherms for dead native biomass of A. nodosum at different $\mathrm{pH}:(\square) \mathrm{pH} 3.5 ;(\diamond) \mathrm{pH} 4.5 ;(\bigcirc) \mathrm{pH} 6.0 .(----)$ Combined biosorption and precipitation metal removal. $(\Theta)$ Nonadjusted $\mathrm{pH}$ metal uptake values after (ם) $1 \mathrm{~h}$ of contact (starting $\mathrm{pH}$ 5.7). 


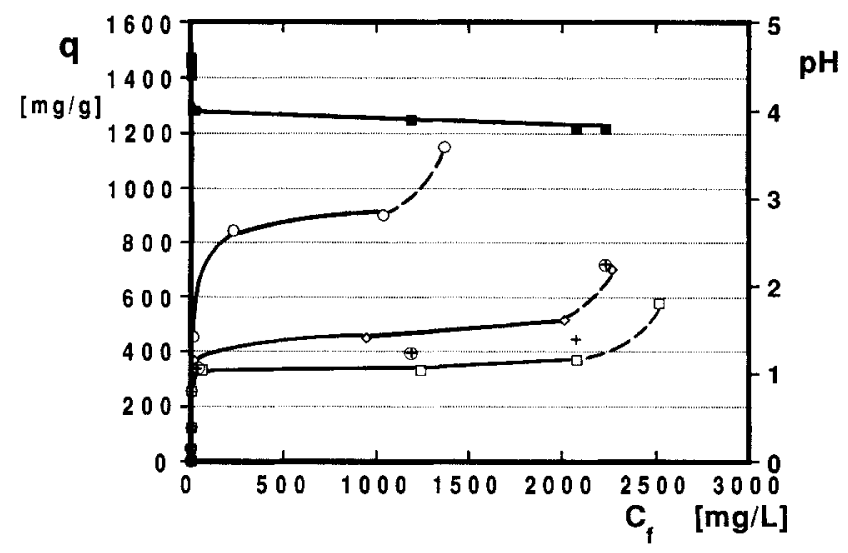

Figure 3. Experimental lead sorption isotherms for Amberlite IR-120 at different $\mathrm{pH}:(\square) \mathrm{pH} 3.5,(\diamond) \mathrm{pH} 4.5,(\mathrm{O}) \mathrm{pH} 6.0 .(-\ldots)$ Combined biosorption and precipitation metal removal. $(\oplus)$ Nonadjusted pH metal uptake values after ( $\mathbf{\square}) 1 \mathrm{~h}$ of contact (starting $\mathrm{pH} 4.6$ ).

system took place within the first hour of the contact and practically did not differ for longer term $(12 \mathrm{~h}$ ) contacts (not specially depicted). There was virtually no precipitation in the A. nodosum sorption system and the constant-pH isotherms deviate more only for $\mathrm{pH} 6$ and at $C_{f}$ exceeding $1800 \mathrm{mg} \mathrm{Pb} / \mathrm{L}$. They follow well the Langmuir model, although the raw native biomass released $27 \%$ of watersoluble material independently of the $\mathrm{pH}$ value. Again, this weight loss was not considered in the calculations of $q$ values.

The substantial difference between $F$. vesiculosus and $A$. nodosum sorption systems was the fact that the latter did not form precipitates up to $C_{i}$ values of 2000 to $3000 \mathrm{mg}$ $\mathrm{Pb} / \mathrm{L}$. The experimental and predicted values for $q_{10}, q_{200}$, $q \max$, and $b$ for the two systems are in Table II. The highest experimental value of $q_{200}$ was about $16.6 \%$ lower for $A$. nodosum than that for $F$. vesiculosus. Somewhat higher experimental values of $q_{10}$ for $A$. nodosum were more favorable than those observed for $F$. vesiculosus, indicating a higher sorption affinity for the metal at low residual concentrations. Large positive differences between the experimental and Langmuir calculated values for $q_{10}$ (A. nodosum in particular) indicate a somewhat lower than theoretical sorbent-sorbate affinity in the low concentration range.

The natural biomass types examined in this work were crosslinked by various procedures resulting in better physical properties (hardness, swelling characteristics, etc.) of the sorbent material but not necessarily its increased metal uptake (Table I). Only in the following samples did crosslinking result in an improved sorption performance in the higher concentration region, as indicated by the values of $q_{200}$ (in comparison with the starting native biomass):

1. F. vesiculosus crosslinked with formaldehyde at buffered $\mathrm{pH} 2$ (not for $q_{10}$ ),

2. A. nodosum crosslinked with bis(ethenyl)sulfone (not for $\left.q_{10}\right)$, and

3. C. crispus crosslinked with 1-chloro-2,3-epoxypropane (also for $q_{10}$ ).

However, at lower concentration ranges (for $q_{10}$ ) the first two processed biosorbents (above) performed worse than the native biomass.

The values of swelling characteristics of the biosorbent particles that were not mentioned earlier ${ }^{14}$ are in Table III. The swelling of biosorbents decreased with the increasing degree of crosslinking even when this was conducted under very mild conditions in a buffered formaldehyde mixture. The native biomass of $A$. nodosum is more dense than parenchymatous particles of $F$. vesiculosus, and it showed higher differences in values of distention index (DI), swelling ratio (Q), and volume of absorbed solvent (VAS) before and after crosslinking. The volume of swelled native $F$. vesiculosus particles increased about $55 \%$ (only $15 \%$ when crosslinked) and VAS was only 0.6 . The difference between the values of $W_{d}$ and $W_{s}$ resulted from the fact that $100 \mathrm{~mL}$ of dry native particles could absorb $239 \mathrm{~mL}$ of water, and only $21 \mathrm{~mL}$ after crosslinking. The corresponding values for $A$. nodosum were 230 and $14 \mathrm{~mL}$, respectively. The advantage of crosslinking is more pronounced in $A$. nodosum.

The performance of commercial ion exchange resins was examined by the same procedure as biosorption. Commercially supplied Duolite GT-73 and Amberlite IR-120 contained $54.7 \%$ and $42 \%$ of water, respectively. Since both

Table III. Swelling characteristics of native and crosslinked $d^{a}$ biomass particles $^{b}$ of $F$. vesiculosus and A. nodosum.

\begin{tabular}{|c|c|c|c|c|c|c|}
\hline Type of material & $\begin{array}{l}\text { Bulk density dry, } \\
\qquad \begin{array}{c}W_{d} \\
(\mathrm{~g} / \mathrm{mL})\end{array}\end{array}$ & $\begin{array}{c}\text { Bulk density wet } \\
\text { swollen, } \\
W_{s} \\
(\mathrm{~g} / \mathrm{mL})\end{array}$ & $\begin{array}{c}\text { Volume swollen, } \\
V_{s} \\
(\mathrm{~mL} / \mathrm{g})\end{array}$ & $\begin{array}{c}\text { Distention index, } \\
\text { DI } \\
\left(V_{s} / W_{d}\right)\end{array}$ & $\begin{array}{c}\text { Swelling ratio, } \\
Q \\
\left(W_{s} / W_{d}\right)\end{array}$ & $\begin{array}{c}\text { Volume of absorbed } \\
\text { solvent, } \\
\text { VAS } \\
{\left[\left(W_{s}-W_{d}\right) / W_{d}\right]}\end{array}$ \\
\hline \multicolumn{7}{|l|}{ A. nodosum } \\
\hline Native & 0.761 & 3.065 & 3.15 & 4.1 & 4.0 & 3.0 \\
\hline Crosslinked & 0.601 & 1.042 & 1.40 & 2.3 & 1.7 & 0.7 \\
\hline \multicolumn{7}{|l|}{ F. vesiculosus } \\
\hline Native & 0.478 & 0.774 & 1.55 & 3.2 & 1.6 & 0.6 \\
\hline Crosslinked & 0.395 & 0.605 & 1.15 & 2.9 & 1.5 & 0.5 \\
\hline
\end{tabular}

${ }^{\text {a }}$ Crosslinked with buffered formaldehyde at $\mathrm{pH} 2$.

${ }^{\mathrm{b}}$ Size of dry particles was $(>1.0 ;<1.4) \mathrm{mm}$. 
resins can withstand temperatures up to $121^{\circ} \mathrm{C}$, according to the Rohm \& Haas Technical Bulletin, they were dried to a constant weight the same way as the biomass samples so that the sorption comparison can be done on an actual "dry weight" basis (not only calculated). They were contacted with the metal-bearing solution under repeated evacuation in order to assure their rewetting even in the entire micropore surface. Table I indicates that Amberlite IR-120 is an excellent sorbent for lead, better than Duolite GT-73. However, their respective lead uptakes did not increase in proportion to the water removed (dry $q_{\max }$ increase: $48.5 \%$ and $108.8 \%$, respectively).

The sorption of lead by dry Amberlite at different $\mathrm{pH}$ as well as the natural decrease of $\mathrm{pH}$ values in $\mathrm{pH}$ nonadjusted control experiments are illustrated in Figure 3 . The experimental and predicted values of $q_{10}, q_{200}, q_{\max }$ are in Table II. The sorption isotherms for the ion exchange resin are very steep. The low $\mathrm{pH}$ of 3.5 was unfavorable; the value of $q_{\max }$ was about $43 \%$ of $q_{\max }$ at $\mathrm{pH} 6.0$. The isotherms at $\mathrm{pH} 3.5$ and 4.5 showed unrealistic increases at values of $C_{f}$ higher than $2000 \mathrm{mg} / \mathrm{L}$. The isotherm for $\mathrm{pH} 6.0$ became unconventional already at $C_{f}=1000 \mathrm{mg}$ $\mathrm{Pb} / \mathrm{L}$ likely due to the (micro) precipitation of lead hydroxides at higher residual concentrations. Correspondingly, the values of calculated $q_{\max }$ were adjusted, disregarding the last high-concentration portion of the isotherms.

\section{Nickel}

The best lead biosorbents were also examined for their nickel uptake. In comparison with the biosorption of lead, the biosorption uptake of nickel by the natural materials examined in this work was almost an order of magnitude lower as judged by the values of $q_{\max }$ (Table IV). The biomass types tested exhibited decreasing affinity for nickel in this sequence: Phaeophyta $>$ Rhodophyta $>$ Chlorophyta. In terms of taxonomic order (represented by limited individual species samples available) the decreasing nickel

Table IV. Experimental and calculated nickel uptake by different types of sorbent materials at $\mathrm{pH} 3.5$.

\begin{tabular}{|c|c|c|c|c|c|c|c|c|}
\hline \multirow[b]{2}{*}{ Sorbent type } & \multicolumn{2}{|c|}{ Experimental } & \multicolumn{4}{|c|}{ Langmuir parameters $^{\mathrm{a}}$} & \multicolumn{2}{|c|}{ Difference $^{b}$} \\
\hline & $\begin{array}{c}q_{10} \\
(\mathrm{mg} / \mathrm{g})\end{array}$ & $\begin{array}{c}9200 \\
(\mathrm{mg} / \mathrm{g})\end{array}$ & $\begin{array}{c}q_{10} \\
(\mathrm{mg} / \mathrm{g})\end{array}$ & $\begin{array}{c}q_{200} \\
(\mathrm{mg} / \mathrm{g})\end{array}$ & $\begin{array}{c}q_{\max } \\
(\mathrm{mg} / \mathrm{g})\end{array}$ & $\begin{array}{c}b \\
\left(\times 10^{2}\right)\end{array}$ & $\begin{array}{l}q_{10} \\
(\%)\end{array}$ & $\begin{array}{l}q_{200} \\
(\%)\end{array}$ \\
\hline \multicolumn{9}{|l|}{ Division Phaeophyta (order Fucales) } \\
\hline Sargassum fluitans ${ }^{\mathrm{c}}$ & 5.6 & 31 & 5.6 & 32 & 44 & 1.46 & 0 & -3.1 \\
\hline S. fluitans ${ }^{\mathrm{d}}$ & 5.5 & 21 & 5.5 & 21 & 24 & 2.94 & 0 & 0 \\
\hline S. fluitans ${ }^{\mathrm{e}}$ & 1.4 & 11 & 1.2 & 11 & 19.8 & 0.67 & 17 & 0 \\
\hline S. natans ${ }^{\mathrm{d}}$ & 2.6 & 19 & 2.6 & 17 & 24 & 1.19 & 0 & 11.8 \\
\hline S. vulgare ${ }^{\mathrm{d}}$ & 1.7 & 4.6 & 1.7 & 4.6 & 5 & 5.26 & 0 & 0 \\
\hline F. vesiculosus ${ }^{\mathrm{f}}$ & 3.6 & 21 & 3.1 & 21 & 31 & 1.12 & 16.1 & 0 \\
\hline$F$. vesiculosus ${ }^{\mathrm{d}}$ & 5.4 & 17 & 5 & 19 & 23 & 2.75 & 8.0 & -11.0 \\
\hline A. nodosum & 8.8 & 34 & 8.8 & 34 & 41 & 2.79 & 0 & 0 \\
\hline A. nodosum ${ }^{\mathrm{g}}$ & 6.8 & 26 & 6.8 & 26 & 30 & 2.89 & 0 & 0 \\
\hline A. nodosum $^{\mathrm{h}}$ & 4.2 & 19 & 4.2 & 19 & 24 & 2.17 & 0 & 0 \\
\hline P. gymnospora ${ }^{\mathrm{d}}$ (Dictyotales) & 0.6 & 5.8 & 0.6 & 5.8 & 10 & 0.67 & 0 & 0 \\
\hline$P \cdot$ gymnospora $^{\mathrm{i}}$ & 2.5 & 12 & 2.5 & 12 & 14 & 2.14 & 0 & 0 \\
\hline \multicolumn{9}{|c|}{ Division Rhodophyta (order Gigartinales) } \\
\hline C. crispus $^{\mathrm{d}}$ & 4.6 & 20 & 4.6 & 21 & 26 & 2.20 & 0 & -4.8 \\
\hline G. marginata ${ }^{\mathrm{d}}$ (Nemalionales) & 0.8 & 6.9 & 0.8 & 6.9 & 11 & 0.79 & 0 & 0 \\
\hline G. marginata ${ }^{\mathrm{i}}$ & 0.2 & 3.3 & 0.2 & 3.3 & 11 & 0.22 & 0 & 0 \\
\hline$P \cdot$ palmata $^{\mathrm{d}, \mathrm{j}}$ (Palamariales) & - & - & - & - & - & - & - & - \\
\hline \multicolumn{9}{|c|}{ Division Chlorophyta (order Codiales) } \\
\hline C. taylori $i^{\mathrm{d}}$ & 1.9 & 5.3 & 1.9 & 5.3 & 5.8 & 4.95 & 0 & 0 \\
\hline Urea-formaldehyde complex & 0.5 & 2.5 & 0.5 & 2.5 & 3.1 & 2.03 & 0 & 0 \\
\hline \multicolumn{9}{|l|}{ Amberlite IR-120 } \\
\hline Wet & 66 & 74 & 66 & 74 & 74 & 8.23 & 0 & 0 \\
\hline Dry & 79 & 119 & 50 & 130 & 143 & 5.89 & 58 & -8.5 \\
\hline \multicolumn{9}{|l|}{ Duolite GT-73 } \\
\hline Wet & 13 & 22 & 13 & 22 & 23 & 12.56 & 0 & 0 \\
\hline Dry & 28 & 46 & 28 & 46 & 48 & 13.91 & 0 & 0 \\
\hline
\end{tabular}

a $q_{10}$ and $q_{200}$ metal uptake at the residual concentrations of 10 and $200 \mathrm{mg} / \mathrm{L}$, respectively.

b $\left(q_{\mathrm{EXP}}-q_{\mathrm{CAL}}\right) 100 / q_{\mathrm{CAL}}$.

${ }^{c}$ Crosslinked with formaldehyde- $\mathrm{HCl}$.

d Native.

e Crosslinked with epichlorohydrin.

${ }^{\mathrm{f}}$ Crosslinked with buffered formaldehyde ( $\mathrm{pH} 2$ ).

$\mathrm{g}$ Crosslinked with formaldehyde and urea.

${ }^{\mathrm{h}}$ Crosslinked with formaldehyde and acetic acid.

${ }^{i}$ After removal of $\mathrm{CaCO}_{3}$.

${ }^{\mathrm{j}} q=3.9 \mathrm{mg} / \mathrm{g}$ at $C_{f}=236 \mathrm{mg} / \mathrm{L}$. 
affinity would be Fucales $>$ Gigartinales $>$ Dictyotales $>$ Nemalionales $>$ Codiales $>$ Palmariales. The native biomass of species belonging to the order Fucales appeared to be a reasonably good sorbent for many metals. For nickel, however, it did not perform too well, exhibiting the following decreasing sorption ability: A. nodosum $>S$. fluitans $>S$. natans $>F$. vesiculosus. The value of $q_{\max }$ for $C$. crispus was close to that for $S$. fluitans. The differences of nickel sorption were diminished in calcareous algae $P$. gymnospora and $G$. marginata for both native biomass types (before removing $\mathrm{CaCO}_{3}$ ) as well as for those with $\mathrm{CaCO}_{3}$ removed.

Crosslinking of $S$. fluitans and $F$. vesiculosus with formaldehyde improved their nickel uptake somewhat. Crosslinking with 1-chloro-2,3,-epoxypropane or with a formaldehyde-urea mixture resulted in decreased metal uptakes as compared with native materials. However, Table $\mathrm{V}$ shows that the nickel sequestering performance $\left(q_{\max }\right)$ of commercial ionex resin Amberlite IR-120 is $70 \%$ higher than that observed for $A$. nodosum at the optimum $\mathrm{pH}$ 6.0. The $q_{\max }$ nickel uptake by hydrated Amberlite was $74.4 \mathrm{mg} / \mathrm{g}$, which can be recalculated to be $164 \mathrm{mg} / \mathrm{g}$ on the dry weight basis (Table IV). The same resin actually dried for the sorption test had $q_{\max }$ $=143 \mathrm{mg} / \mathrm{g}$, corresponding to $87 \%$ of the calculated value (above).

The sorption of nickel at different controlled $\mathrm{pH}$ values is summarized in Figure 4 together with results for sorption systems with nonadjusted $\mathrm{pH}$. These results demonstrate the increasing uptake of nickel with increasing $\mathrm{pH}$ values for native biomass $A$. nodosum and in Figure 5 also for commercial resin Amberlite IR 120. Contrary to lead isotherms, nickel isotherms followed the Langmuir model well, and the differences between the experimental and calculated values of $q_{10}$ and $q_{200}$ were zero or very small.

\section{DISCUSSION}

This work identified three types of brown marine algae biomass (dead) as excellent sorption materials for binding lead well in excess of $20 \%$ of the material dry weight. According to the maximum lead uptake $\left(q_{\max }\right)$ the native (raw) biomass types performed in the following order: $F$. vesiculosus $>A$. nodosum $>S$. fluitans. Processing of the biomass by crosslinking can improve its physical properties (strength, hardness, swelling characteristics, etc.) required for column sorption applications without adversely affecting the sorption, which in some cases may even increase. Nickel sorption by the same biomass types was almost an order of magnitude lower.

There is a scientific and practical interest in locating the active sites of the biopolymeric structures of the biomass that are responsible for the sorption. Recently, Kloareg et al. ${ }^{15}$ outlined the semispeculative model of the structure of cell walls of brown algae: The cellulose chains formed the structural and rigid network in which four other biopolymers (alginates, xylofucoglucans, xylofucoglycuronans, and homofucans) are embedded. Similarity of fucose-containing polysaccharides of cell walls of several genera of brown algae as well as the variations of the sugar constituents of algal polysaccharides were also described. ${ }^{18,19}$ Although the algal species examined in this work for their metal sequestering ability differed taxonomically, their biomass featured two common moieties:

1. Sulfate esters in the cellular polysaccharides including:

a. Fucoidans (after removal of alginates) in the division Phaeophyta with $\mathrm{O}-\mathrm{SO}_{3}{ }^{-}$groups at carbons $\mathrm{C}_{2}$ or $\mathrm{C}_{3}$ or containing disulfate esters at $C_{2}$ and $C_{3}$ in $\alpha-1,4$-linked L-fucopyranosyl residues. Sulfate esters were described in 21 species, including Fucus vesiculosus, Sargassum thurnbergii, and Padina arborescens. ${ }^{19}$

b. Carrageenans, agars, porphyrans, furcellarans, funorans, etc. in the division Rhodophyta. They are sulfated galactans at $\mathrm{C}_{2}$ or $\mathrm{C}_{4}$ or $\mathrm{C}_{6}$ (disulfate esters at $C_{2}$ and $C_{6}$ were identified in $\lambda$-carrageenan) with different proportions of 1,3- and 1,4-D,L-linked galactosyl residues. ${ }^{25}$

Table V. Experimental and calculated nickel uptake by different types of native sorbent materials at different $\mathrm{pH}$.

\begin{tabular}{|c|c|c|c|c|c|c|c|c|}
\hline \multirow[b]{2}{*}{ Sorbent type } & \multicolumn{2}{|c|}{ Experimental } & \multicolumn{4}{|c|}{ Langmuir parameters $^{\mathrm{a}}$} & \multicolumn{2}{|c|}{ Difference $^{b}$} \\
\hline & $\begin{array}{c}q_{10} \\
(\mathrm{mg} / \mathrm{g})\end{array}$ & $\begin{array}{c}q_{200} \\
(\mathrm{mg} / \mathrm{g})\end{array}$ & $\begin{array}{c}q_{10} \\
(\mathrm{mg} / \mathrm{g})\end{array}$ & $\begin{array}{c}q 200 \\
(\mathrm{mg} / \mathrm{g})\end{array}$ & $\begin{array}{c}q_{\max } \\
(\mathrm{mg} / \mathrm{g})\end{array}$ & $\begin{array}{c}b \\
\left(\times 10^{2}\right)\end{array}$ & $\begin{array}{l}q_{10} \\
(\%)\end{array}$ & $\begin{array}{l}q_{200} \\
(\%)\end{array}$ \\
\hline \multicolumn{9}{|l|}{ A. nodosum } \\
\hline Nonadjusted pH & $10(\mathrm{pH} \mathrm{5})$ & $64(\mathrm{pH} \mathrm{4.6)}$ & - & - & - & - & - & - \\
\hline pH 3.5 & 11 & 60 & 11 & 60 & 79 & 1.56 & 0 & 0 \\
\hline $\mathrm{pH} 4.5$ & 9 & 64 & 9 & 72 & 117 & 0.80 & 0 & -11.0 \\
\hline $\mathrm{pH} 6.0$ & 11 & 70 & 7 & 72 & 136 & 0.56 & 57 & -2.8 \\
\hline \multicolumn{9}{|c|}{ Amberlite IR-120 (dry) } \\
\hline Nonadjusted pH & $82(\mathrm{pH} \mathrm{5.5)}$ & $127(\mathrm{pH} \mathrm{5.6)}$ & - & - & - & - & - & - \\
\hline $\mathrm{pH} 3.5$ & 79 & 119 & 50 & 130 & 143 & 5.38 & 58 & -8.5 \\
\hline $\mathrm{pH} 4.5$ & 87 & 119 & 37 & 146 & 173 & 2.68 & 135 & -18.0 \\
\hline $\mathrm{pH} 6.0$ & 82 & 129 & 24 & 160 & 230 & 1.14 & 242 & -19.0 \\
\hline
\end{tabular}

${ }^{\text {a }} q_{10}$ and $q_{200}$ metal uptake at the residual concentrations of 10 and $200 \mathrm{mg} / \mathrm{L}$, respectively.

${ }^{\mathrm{b}}\left(q_{\mathrm{EXP}}-q_{\mathrm{CAL}}\right) 100 / q_{\mathrm{CAL}}$. 


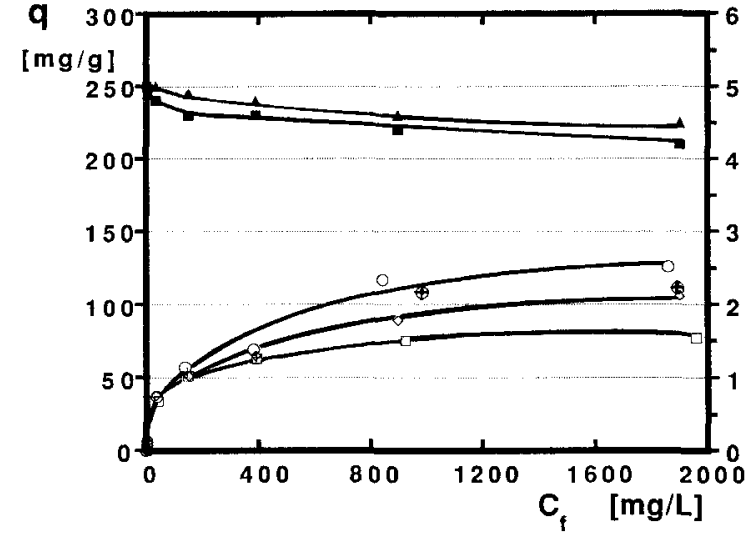

Figure 4. Experimental nickel sorption isotherms for dead native

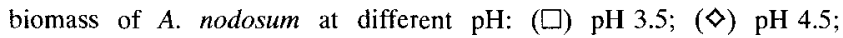
(O) $\mathrm{pH}$ 6.0. ( $\oplus$ ) Nonadjusted $\mathrm{pH}$ metal uptake values after $(\boldsymbol{\Lambda}) 1 \mathrm{~h}$ and (ש) $14 \mathrm{~h}$ of contact (starting $\mathrm{pH} 5.1$ ).

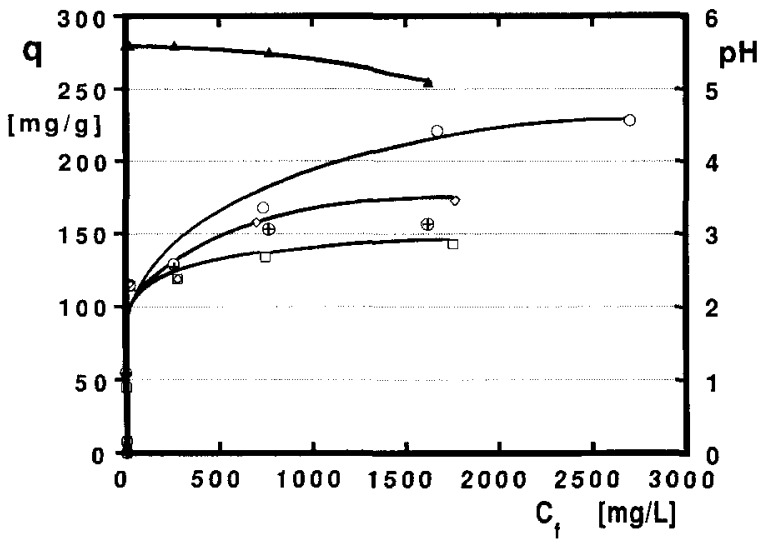

Figure 5. Experimental nickel sorption isotherms for dry Amberlite

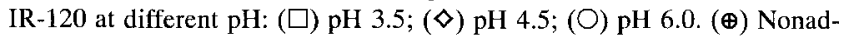
justed $\mathrm{pH}$ metal uptake values after $(\boldsymbol{\Delta}) 1 \mathrm{~h}$ of contact (starting $\mathrm{pH} 4.8$ ).

c. Sulfate esters at $\mathrm{C}_{2}$ and $\mathrm{C}_{6}$ of $\beta-1,3-$ galactans are present in $C$. taylori (division Chlorophyta). ${ }^{4}$

2. The presence of polyuronides that are represented by galacturonic, glucuronic, guluronic and mannuronic acids in all three divisions mentioned above.

The carboxyl groups, present abundantly in the four mentioned uronic acids, together with sulfate groups, could be considered as ligands mainly responsible for the bulk of metal sorption. ${ }^{6}$

Indications of advantages of morphologically different architecture of algal tissues in relation to increasing the metal biosorbent uptake could be seen in comparing the sorption performance of $F$. vesiculosus and A. nodosum. The thallus of the former consists of parenchymatous cells with apical meristems ${ }^{5}$ instead of the predominantly filamentous architecture of the latter. The architecture of parenchymatous cells represents a greatly increased surface area which is available for sorption. Comparison of the density of crosslinked particles of $F$. vesiculosus and
A. nodosum indicated a $34 \%$ higher density of the latter (Table III). This means that morphological differences existing within the same order can influence the sorption process. Also the structure of alginates present can differ between young and old tissues as well as between different parts of the same plant. ${ }^{12}$ The content of sulfate groups as well as uronic acids in the algal biomass examined differ not only between species but even seasonally and geographically within the same species, ${ }^{21}$ the variations being responsible for potentially differing sorption capabilities.

To study the sorption of metals which tend to form insoluble (micro)precipitates becomes more complicated due to the fact that the collection of the metal species is not due to the "straight" sequestration mechanism. In the case of lead in particular its solution chemistry is more complex. Addition of $\mathrm{NaOH}$, which may be used to adjust the $\mathrm{pH}$ of the solution of lead nitrate, ${ }^{10,20}$ likely results in the formation of insoluble $\mathrm{Pb}\left(\mathrm{NO}_{3}\right)_{2} \mathrm{~Pb}(\mathrm{OH})_{2}$ and $\mathrm{Pb}\left(\mathrm{NO}_{3}\right)_{2} 5 \mathrm{~Pb}(\mathrm{OH})_{2}$ complexes, which in turn result in distortion of the sorption results. This is a reason to use $\mathrm{NH}_{4} \mathrm{OH}$ for the least interfering $\mathrm{pH}$ adjustment of the sorption system. The danger of microprecipitation starts at $\mathrm{pH}$ above 5.0 for lead and at $\mathrm{pH} 6.7$ for nickel. ${ }^{3}$

The formation of amphoteric lead hydroxides causes a problem with $\mathrm{pH}$ adjustment in the study of sorption systems. Metal ions are coordinated by water molecules that cause a hydrolytic reaction:

$$
\mathrm{M}^{n+}+\mathrm{H}_{2} \mathrm{O} \longrightarrow(\mathrm{MOH})^{(n-1)+}+\mathrm{H}^{+}
$$

or more realistically:

$$
\mathrm{M}\left(\mathrm{H}_{2} \mathrm{O}\right)_{x}^{n+} \longrightarrow\left[\mathrm{M}\left(\mathrm{H}_{2} \mathrm{O}\right)_{(x-1)}(\mathrm{OH})\right]^{(n-1)+}+\mathrm{H}^{+}
$$

The dissociation of amphoteric hydroxides (which are weak acids) points to the fact that the higher the number of covalent $\mathrm{M}-\mathrm{O}$ bonds, the more acidic are the hydrogen atoms in the aquated ion, and the following neutralization of protons results in further releasing of protons. Moreover, the hydroxide ion has the ability to form bridges between metal ions. The most common example is the formation of hydroxobridges at an early stage of the precipitation of hydrous metal oxides:<smiles>[M]O[TlH]</smiles>

When the solution becomes uncharged, the resulting $\mathrm{pH}$ represents an isoelectric point with the lowest solubility of metal ions. Whereas this situation is very favorable for the sorbent deposition of metals, it may make the study of the binding sites more difficult. Another favorable feature of the above-mentioned equation is the fact that the addition of water (or other neutral groups) does not alter the valency, but increases the molecular mass of the complex formed, thus favoring the sorbate deposition. Whereas microprecipitation occurring in the sorption system can complicate the study of sorption, from the process application point of view it may desirably augment the metal immobilization, 
thus increasing the apparent overall uptake capacity of biosorbent materials.

There was a conspicuous difference observed in this work between the biosorbent uptake of lead and nickel. Several factors may be responsible for this difference. The lead and nickel sorption follows the general rule that metal sorption increases with increasing valence and atomic number. The lower sorption of nickel in comparison to lead could be related to the fact that nickel has much lower selectivity coefficient for alginates than lead, which features the highest one reflected in the highest values of alginate gel shrinkage. ${ }^{22}$ Nickel belongs to the intermediate metals with high affinity not only to ligands like phosphoryl, $-\mathrm{SO}_{3}{ }^{2-}, \mathrm{R}-\mathrm{NH}_{2}$, and $\mathrm{R}_{2}-\mathrm{NH}$ but mainly to $-\mathrm{COO}^{-}$ groups which it likely shares with lead. The cis position of sulfate esters at $C_{3}$ and $C_{4}$ of the branched fucose residue may be instrumental in the covalent binding of lead only to one residue. However, the same site could sequester nickel by an ion exchange mechanism. Sulfate groups at other carbons could assist in forming covalent bonds between adjacent chains of fucoidans and other sulfated polysaccharides. This covalent bond (polysaccharide $-\mathrm{O}-\mathrm{SO}_{3}-\mathrm{Pb}-\mathrm{SO}_{3}-\mathrm{O}-$ polysaccharide) practically represents another type of crosslinking worthy of attention in studies of the metal-loaded behavior during desorption.

The higher sorption values observed with several crosslinked types of biomass revealed an additional advantage of crosslinking because the majority of sulfate groups and uronic acids present in the cellular polysaccharides could be covalently attached to the structural polysaccharide network. The crosslinking of $A$. nodosum native biomass with bis(ethenyl)sulfone confirmed the possibility of increasing the sorption capacity of the biosorbent material by incorporation of sulfone groups. Free aldehydic groups originating from dialdehydes used for crosslinking and incompletely anchored at one end only could, after reduction of metal ions and oxidation of aldehydic groups to carboxyl groups, also possibly increase the sorption capacity of a prepared biosorbent.

\section{References}

1. Al Amondi, O.A., El-Naggar, M.E. 1987. Distribution of heavy metals in a species of Caulerpa from Shauba, Saudi Arabia. Microbios 52: $81-85$.

2. Barnett, B., Forbes, S. Ashcroft, C. 1989. Heavy metals on the south bank of the Humber estuary. Mar. Pollut. Bull. 20: 17-21.

3. Britton, H. T. S. 1943. The application of electrometric methods to the study of some ionic reactions. Annu. Rep. Prog. Chem. 40: 43-59.

4. Chapman, A. R. O. 1978. Chlorophyta. pp. 381-399 In: A. I. Laskin and H. A. Lachevalier (eds.), CRC handbook of microbiology, vol. 2, 2nd edition. CRC Press, Boca Raton, FL.

5. Chapman, A. R. O. 1978. Phaeophyta. pp. 401-410 In: A. I. Laskin and H. A. Lechevalier (eds.), CRC handbook of microbiology, vol. 2, 2nd edition. CRC Press, Boca Raton, FL.
6. Crist, R. H., Oberholser, K., McGarrity, J., Crist, D. R., Johnson, J. K., Brittsan, J. M. 1992. Interaction of metals and protons with algae. 3. Marine algae, with emphasis on lead and aluminum. Environ. Sci. Technol. 26: 496-502.

7. Darnall, D.W. 1991. Removal and recovery of heavy metals from wastewaters using a new biosorbent AlgaSORB. Innovative Hazard Waste Treatment Technol., Ser. Biol. Proc. 3: 65-72.

8. Fayed, S. E., Abd-El-Shafy, H. I. 1985. Accumulation of copper, zinc, cadmium and lead by aquatic macrophytes. Environ. Int. 11: 77-87.

9. Forsberg, A., Soederlund, S., Peterson, L. R., Pedersen, M. 1988. Studies on metal content in the brown seaweed Fucus vesiculosus from the archipelago of Stockholm. Environ. Pollut. 49: 245-263.

10. Fourest, E., Roux, J.-C. 1992. Heavy metal biosorption by fungal mycelial by-products: Mechanisms and influence of pH. Appl. Microbiol. Biotechnol. 37: 399-403.

11. Greene, H., Darnall, D.W. 1988. Temperature dependence of metal ion sorption by Spirulina. Biorecovery 1: 27-41.

12. Haug, A., Larsen, B., Smidsrod, O. 1974. Uronic acid sequence in alginate from different sources. Carbohydr. Res. 32: 217-255.

13. Ho, Y. B. 1990. Ulva lactuca as bioindicator of metal contamination in intertidal waters of Hong Kong. Hydrobiologia 209: 73-81.

14. Holan, Z. R., Volesky, B., Prasetyo, I. 1993. Biosorption of cadmium by biomass of marine algae. Biotechnol. Bioeng. 41: 819-825.

15. Kloareg, B., Demarty, M., Mabeau, S. 1986. Polyanionic characteristics of purified sulfated homofucans from brown algae. Int. J. Biol. Macromol. 8: 380-386.

16. Kubiak, W. W., Wang, J., Darnall, D. 1989. Algal columns with anodic stripping voltametric detection. Anal. Chem. 61: 468-471.

17. Kuyucak, N., Volesky, B. 1990. Biosorption by algal biomass. pp. 173-198 In: B. Volesky (ed.), Biosorption of heavy metals. CRC Press, Boca Raton, FL.

18. Mabeau, S., Kloareg, B., Joseleau, J.P. 1990. Fractionations and analysis of fucans from brown algae. Phytochemistry. 29: 2441-2445.

19. Nishida, E., Anzai, H., Uchida, N., Nisizawa, K. 1990. Sugar constituents of fucose-containing polysaccharides from various Japanese brown algae. Hydrobiologia 204/205: 573-576.

20. Niu, H., Xu, X. S., Wang, J. H., Volesky, B. 1993. Removal of lead from aqueous solutions by Penicillium biomass. Biotechnol. Bioeng. 42: $785-787$.

21. Percival, E., McDowell, R.H. 1967. Chemistry and enzymology of marine algal polysaccharides. 137-143. Academic, London.

22. Percival, E., McDowell, R.H. 1967. Chemistry and enzymology of marine algal polysaccharides. 118-120. Academic, London.

23. Pfarr, R., Neeb, R. 1990. Organic solvent-soluble contents of nickel and cobalt in some algae. Naturwissenschaften 77: 383-384.

24. Sharp, G. J., Samant, H. S., Vaidya, O. C. 1988. Selected metal levels of commercially valuable seaweeds adjacent to and distant from point sources of contamination in Nova Scotia and New Brunswick. Bull. Environ. Contam. Toxicol. 40: 724-730.

25. Stevenson, T. T., Furneaux, R. H. 1991. Chemical methods for the analysis of sulphated galactans from red algae. Carbohydr. Res. 210: $277-298$.

26. Volesky, B. (ed.). 1990. Biosorption of heavy metals. CRC Press, Boca Raton, FL.

27. Volesky, B., Kuyucak, N. 1988. Biosorbent for gold. U.S. Patent $4,769,223$.

28. Vymazal, J. 1990. Toxicity and accumulation of lead with respect to algae and cyanobacteria: A review. Acta Hydrochim. Hydrobiol. 18: $513-535$.

29. Vymazal, J. 1990. Uptake of heavy metals by Cladophora glomerata. Acta Hydrochim. Hydrobiol. 18: 657-665.

30. Wong, P. K., Wong, C. K. 1990. Toxicity of nickel and nickel electroplating water to Chlorella pyrenoidosa. Bull. Environ. Contam. Toxicol. 45: 752-759. 